(RESEARCH ARTICLE)

\title{
Demographic details of oral hygiene practice and dental service utilization of Medical Doctors in Port Harcourt
}

\author{
Modupeoluwa Omotunde Soroye ${ }^{1,{ }^{*}}$ and Richard Ishmael Oko-Jaja ${ }^{2}$ \\ ${ }^{1}$ Department of Preventive Dentistry, Faculty of Dentistry, College of Health Science, University of Port Harcourt, Port \\ Harcourt, Rivers State, Nigeria \\ ${ }^{2}$ Department of Medicine, College of Health Science, University of Port Harcourt, Port Harcourt, Rivers State, Nigeria
}

Publication history: Received on 27 October 2020; revised on 03 November 2020; accepted on 05 November 2020

Article DOI: https://doi.org/10.30574/wjarr.2020.8.2.0403

\begin{abstract}
Maintenance of good oral hygiene practice is the key to having a good oral health and invariably, an improved quality of life. Consecutive consenting medical practitioners attending the 2019 National Medical Association Annual General Meeting were recruited for this study. Data was analyzed using the Statistical Package for Social Sciences version 20.0 (IBM SPSS Statistics Armonk New York). One hundred and fifty-six participants were recruited. Ninety-four (60.3\%) were male and 62(39.7\%) females. Age ranged between 23 and 72 years with a mean age of $41.6 \pm 11.18$ years. Almost all participants cleaned their teeth with toothbrush and fluoridated toothpaste. More males, more consultants and more participants in the federal hospital brushed their teeth twice daily and used medium bristled toothbrushes. Equal number of males and females used dental floss and interdental brushes. More consultants than all other cadre of participants and more participants in the federal hospital used dental floss $(\mathrm{p}=0.02)$. More participants in the federal hospital visited the dentist in the past $(\mathrm{p}=0.05)$; however, more males and more consultants did not have time to visit. Twice the participants with six to ten years of practice compared to those with more than fifteen years of practice did not access dental service because they felt they had no dental problem $(p=0.248)$. The longer the year of medical practice, the better the oral hygiene practice. One out of every 5 participants regularly visit the dentists; a consultant will likely visit more regularly than other designated participants.
\end{abstract}

Keywords: Oral hygiene practice; Dental utilization; Demographics; Medical doctors

\section{Introduction}

Good oral health improves quality of life. Oral health has been described as the standard of health of the oral and related tissues which enables an individual to eat, speak and socialize without active disease, discomfort or embarrassment and which contributes to general well-being [1].

Oral hygiene is the practice of keeping one's mouth clean and free of diseases such as gingivitis (inflammation of the gingiva) and periodontitis (inflammation of the periodontal tissues) and other oral problems (for example, bad breath) by regular tooth brushing and interdental cleaning (cleaning in between the teeth) [2].

Generally, it has been advocated that to maintain a good oral hygiene, toothbrushing should be done at least twice daily using fluoridated toothpaste; after breakfast and before going to bed. Tooth brushing is the mechanical removal of dental plaque from tooth surfaces. The oral cavity contains commensal microflora which can switch to opportunistic pathogenic flora through complex changes in their environment [3-5]. Dental plaque contains microorganisms in a

\footnotetext{
${ }^{*}$ Corresponding author: Modupeoluwa Omotunde Soroye

Department of Preventive Dentistry, Faculty of Dentistry, College of Health Science, University of Port Harcourt, Port Harcourt, Rivers State, Nigeria.
}

Copyright $(2020$ Author(s) retain the copyright of this article. This article is published under the terms of the Creative Commons Attribution Liscense 4.0. 
dynamic environment forming a biofilm and producing hormones and by-products that stimulate the host immune system and can harm the teeth and their supporting tissues [4,6,7].

Furthermore, it is difficult to clean all the teeth surfaces with the toothbrush alone as $40 \%$ of them are interdental [8]. It is important to clean the interdental spaces with interdental cleaning aids such as dental floss and interdental brushes or tapes. It has been reported that $80 \%$ of dental plaque can be removed by flossing [9]. Thus, interdental cleaning is as important as tooth brushing [2].

The use of toothpicks is not encouraged, and though these items are readily available in Nigeria, they can cause trauma to the gingivae and cause systemic complications if accidentally ingested [10-15]. Toothpicks are used to remove food debris that are trapped between teeth after meals especially meals that contain proteins and fibres.

There is the need to access dental services especially now that good oral health is seen as essential to maintaining general health and well-being [16] It has been reported that people who visit the dentist more frequently have better oral health and fewer oral problems and are more satisfied with their oral health when compared with those who do not [17-19].

Several reasons have been reported for failure to access dental services promptly and regularly. These are feelings that symptoms will resolve on its own, trying other medications, financial constraints, feelings of no dental problems, bad dental experience, fear of dental treatments, among others [20,21].

To the best knowledge of the authors, no study has been done on the oral hygiene practice of doctors in Port Harcourt, South-South of Nigeria. This study therefore, examined the association between the oral hygiene practice and dental service utilization of the medical doctors in Port Harcourt based on demographics.

\section{Material and methods}

This was a cross-sectional study done among medical doctors in Port Harcourt. All consenting consecutive medical practitioners that attended the 2019 Annual General Meeting of the Nigeria Medical Association of Nigeria, Port Harcourt; Rivers States Branch that held in August, 2019 were recruited for this study.

Participants were in practice in private hospitals, state hospitals (Brathwaite Memorial Hospital and Primary Health Centers) and federal hospital (University of Port Harcourt Teaching Hospital).

Self-administered questionnaires that elicited the participants demographics were used to obtain information on oral hygiene practice and dental service utilization.

Ethical approval for the study was obtained from the University of Port Harcourt Teaching Hospital Research and Ethics Committee.

Data was analysed using the Statistical Package for Social Sciences version 20.0 (IBM SPSS Statistics Armonk New York). The results were presented as tables and cross-tabulations. Chi-square test was carried out for statistical significance. $\mathrm{P}<0.05$ was considered statistically significant.

\section{Results}

One hundred and fifty-six medical practitioners were recruited for this study, 94(60.3\%) were male and 62(39.7\%) were females giving a M: F of 1:1.52. Age ranged between 23 and 72 years with a mean age of $41.6 \pm 11.18$ years. Fortythree percent of participants were consultants in different fields of medicine and thirty four percent had been in practice for over fifteen years. Table 1 
Table 1 Participants Demographics

\begin{tabular}{|c|c|c|}
\hline Variables & Frequency & Percentage \\
\hline \multicolumn{3}{|l|}{ Sex } \\
\hline Male & 94 & 60.3 \\
\hline Female & 62 & 39.7 \\
\hline \multicolumn{3}{|l|}{ Age Group } \\
\hline $21-30$ & 18 & 11.6 \\
\hline $31-40$ & 69 & 44.2 \\
\hline $41-50$ & 35 & 22.5 \\
\hline $51-60$ & 20 & 12.8 \\
\hline $61-70$ & 13 & 8.3 \\
\hline$>70$ & 1 & 0.6 \\
\hline \multicolumn{3}{|l|}{ Tribe } \\
\hline Yoruba & 4 & 2.6 \\
\hline Igbo & 31 & 19.9 \\
\hline South-South & 121 & 77.6 \\
\hline \multicolumn{3}{|l|}{ Designation } \\
\hline House officer & 11 & 7.1 \\
\hline Registrar & 42 & 26.9 \\
\hline Senior registrar & 35 & 22.4 \\
\hline Consultants & 68 & 43.6 \\
\hline \multicolumn{3}{|l|}{ Practise(years) } \\
\hline $0-5$ & 30 & 19.2 \\
\hline $6-10$ & 46 & 29.5 \\
\hline $11-15$ & 27 & 17.3 \\
\hline$>15$ & 53 & 34.0 \\
\hline Total & 156 & 100.0 \\
\hline
\end{tabular}

Table 2 shows the association between participants oral hygiene practice and demographics (gender, designation and year of practice). Almost all participants brushed with toothbrush and fluoridated toothpaste. More males than females $\{53(56.4 \%) ; 41(43.6 \%)\}$, equal number of registrars and senior registrars $\{23(24.5 \%)\}$, more consultants $\{41(43.5 \%)\}$, more participants $\{50(53.2 \%)\}$ in the federal hospital and those with more than fifteen years of practice brushed their teeth twice daily. More males $\{58(56.9 \%)\}$, more consultants $\{47(46.1 \%)\}$, more participants $\{49(48 \%)\}$ in the federal hospital used medium bristled toothbrushes. Few participants $\{5(2.2 \%)\}$ brushed with roll technique.

As regards the use of interdental cleaning aids; equal number of males and females $\{36(50 \%)\}$ used dental floss and interdental brushes. More consultants $\{36(50 \%)\}$ than all other cadre of participants used dental floss. Statistical analysis showed no statistical significance Table 2.

Table 3 shows the association between oral hygiene practise and year of practise. The longer the year of medical practise, the better the oral hygiene practise. 
Table 2 Association between participants oral hygiene practice and some demographics

\begin{tabular}{|c|c|c|c|c|c|c|c|c|c|c|c|c|c|c|}
\hline \multirow{3}{*}{\multicolumn{2}{|c|}{ Variables }} & \multirow{3}{*}{\begin{tabular}{|l} 
Total \\
\\
$N(\%)$
\end{tabular}} & \multicolumn{2}{|l|}{ Gender } & \multicolumn{5}{|c|}{ Designation } & \multirow{3}{*}{ 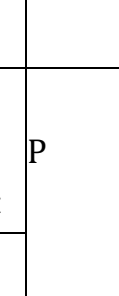 } & \multicolumn{3}{|l|}{ Centre } & \multirow{3}{*}{$\mathrm{p}$} \\
\hline & & & & & \multirow{2}{*}{ 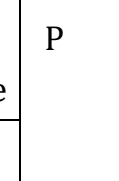 } & \multirow{2}{*}{ 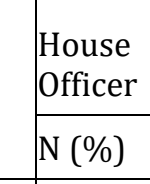 } & \multirow{2}{*}{\begin{tabular}{|l} 
Registrar \\
$\mathrm{N}(\%)$
\end{tabular}} & \multirow{2}{*}{$\begin{array}{l}\text { Senior } \\
\text { Registrar }\end{array}$} & \multirow{2}{*}{\begin{tabular}{|l|} 
Consultant \\
$\mathrm{N}(\%)$ \\
\end{tabular}} & & \multirow{2}{*}{\begin{tabular}{|l} 
Private \\
Hospital
\end{tabular}} & \multirow{2}{*}{\begin{tabular}{|l} 
State \\
Hospital
\end{tabular}} & \multirow{2}{*}{\begin{tabular}{|l} 
Federal \\
Hospital
\end{tabular}} & \\
\hline & & & N (\%) & $\mathrm{N}(\%)$ & & & & & & & & & & \\
\hline \multirow{2}{*}{$\begin{array}{l}\text { Teeth } \\
\text { cleaning } \\
\text { material }\end{array}$} & $\begin{array}{l}\text { Toothbrush and } \\
\text { paste }\end{array}$ & $144(92.3)$ & $86(59.7)$ & $58(40.3)$ & \multirow[t]{2}{*}{0.637} & $11(7.6)$ & $39(27.1)$ & $33(22.9)$ & $61(42.4)$ & \multirow[t]{2}{*}{0.620} & $27(18.8)$ & $47(32.6)$ & $70(48.6)$ & \multirow[t]{2}{*}{0.451} \\
\hline & $\begin{array}{l}\text { Toothbrush } \\
\text { paste + chewing } \\
\text { stick }\end{array}$ & $12(7.7)$ & $8(66.7)$ & $4(33.3)$ & & $0(0.0)$ & $3(25.0)$ & $2(16.7)$ & $7(58.3)$ & & $1(8.3)$ & $3(25.0)$ & $8(66.7)$ & \\
\hline \multirow{4}{*}{$\begin{array}{l}\text { Frequency of } \\
\text { brushing }\end{array}$} & Once daily & $60(38.5)$ & $40(66.7)$ & $20(33.3)$ & \multirow[t]{4}{*}{0.285} & $4(6.7)$ & $18(30.0)$ & $12(20.0)$ & $26(43.3)$ & \multirow[t]{4}{*}{0.852} & $16(26.7)$ & $16(26.7)$ & $28(46.7)$ & \multirow[t]{4}{*}{0.164} \\
\hline & Twice daily & $94(60.3)$ & $53(56.4)$ & $41(43.6)$ & & $7(7.4)$ & $23(24.5)$ & $23(24.5)$ & $41(43.6)$ & & $12(12.8)$ & $32(34.0)$ & $50(53.2)$ & \\
\hline & Every other day & $1(0.6)$ & $0(0.0)$ & $1(100.0)$ & & $0(0.0)$ & $0(0.0)$ & $0(0.0)$ & $1(100.0)$ & & $0(0.0)$ & $1(100.0)$ & $0(0.0)$ & \\
\hline & After every meal & $1(0.6)$ & $1(100.0)$ & $0(0.0)$ & & $0(0.0)$ & $1(100.0)$ & $0(0.0)$ & $0(0.0)$ & & $0(0.0)$ & $1(100.0)$ & $0(0.0)$ & \\
\hline \multirow[t]{3}{*}{ Type of brush } & Soft & $25(16.0)$ & $15(60.0)$ & $10(40.0)$ & \multirow[t]{3}{*}{0.320} & $2(8.0)$ & $7(28.0)$ & $9(36.0)$ & $7(28.0)$ & \multirow[t]{3}{*}{0.639} & $3(12.0)$ & $11(44.0)$ & $11(44.0)$ & \multirow[t]{3}{*}{0.400} \\
\hline & Medium & $102(65.4)$ & $58(56.9)$ & $44(43.1)$ & & $7(6.9)$ & $28(27.5)$ & $20(19.6)$ & $47(46.1)$ & & $20(19.6)$ & $33(32.4)$ & $49(48.0)$ & \\
\hline & Hard & $29(18.6)$ & $21(72.4)$ & $8(27.6)$ & & $2(6.9)$ & $7(24.1)$ & $6(20.7)$ & $14(48.3)$ & & $5(17.2)$ & $6(20.7)$ & $18(62.1)$ & \\
\hline \multirow{4}{*}{$\begin{array}{l}\text { Brushing } \\
\text { technique }\end{array}$} & Horizontal $(\mathrm{H})$ & $11(7.1)$ & $6(54.5)$ & $5(45.5)$ & \multirow[t]{4}{*}{0.779} & $1(1.9)$ & $4(36.4)$ & $2(18.2)$ & $4(36.4)$ & \multirow[t]{4}{*}{0.727} & $3(27.3)$ & $5(45.5)$ & $3(27.3)$ & \multirow[t]{4}{*}{0.178} \\
\hline & Vertical (V) & $41(26.3)$ & $25(61.0)$ & $16(39.0)$ & & $3(7.3)$ & $6(14.6)$ & $10(24.4)$ & $22(53.7)$ & & $3(7.3)$ & $14(34.1)$ & $24(58.5)$ & \\
\hline & $\mathrm{H}+\mathrm{V}$ & $99(63.5)$ & $61(61.6)$ & $38(38.4)$ & & $7(7.1)$ & $31(31.3)$ & $21(21.2)$ & $40(40.4)$ & & $20(20.2)$ & $31(31.3)$ & $48(48.5)$ & \\
\hline & Roll & $5(3.2)$ & $2(40.0)$ & $3(60.0)$ & & $0(0)$ & $1(20.0)$ & $2(40.0)$ & $2(40.0)$ & & $2(40.0)$ & $0(0.0)$ & $3(60.0)$ & \\
\hline
\end{tabular}


World Journal of Advanced Research and Reviews, 2020, 08(02), 141-151

\begin{tabular}{|c|c|c|c|c|c|c|c|c|c|c|c|c|c|c|}
\hline \multirow{2}{*}{$\begin{array}{l}\text { Interdental } \\
\text { Cleaning }\end{array}$} & Yes & $137(87.8)$ & $82(59.9)$ & $55(40.1)$ & \multirow[t]{2}{*}{0.783} & $9(6.6)$ & $38(27.7)$ & $29(21.2)$ & $61(44.5)$ & \multirow[t]{2}{*}{0.641} & $24(17.5)$ & $42(30.7)$ & $71(51.8)$ & \multirow[t]{2}{*}{0.461} \\
\hline & No & $19(12.2)$ & $12(63.2)$ & $7(36.8)$ & & $2(10.5)$ & $4(21.1)$ & $6(31.6)$ & $7(36.8)$ & & $4(21.1)$ & $8(42.1)$ & $7(36.8)$ & \\
\hline Total & & $156(100.0)$ & $94(60.3)$ & $62(39.7)$ & & $11(7.1)$ & $42(6.9)$ & $35(22.4)$ & $68(43.6)$ & & $28(17.9)$ & $50(32.1)$ & $78(50.0)$ & \\
\hline \multirow{3}{*}{$\begin{array}{l}\text { Reasons for } \\
\text { not cleaning } \\
\text { interdentally } \\
(n=19\end{array}$} & No time & $8(42.1)$ & $5(62.5)$ & $3(37.5)$ & \multirow[t]{3}{*}{0.839} & $0(0.0)$ & $4(50.0)$ & $2(25.0)$ & $2(25.0)$ & \multirow[t]{3}{*}{0.077} & $2(25.0)$ & $3(37.5)$ & $3(37.5)$ & \multirow[t]{3}{*}{0.825} \\
\hline & Not available & $7(36.8)$ & $4(57.1)$ & $3(42.9)$ & & $2(28.6)$ & $0(0.0)$ & $3(42.9)$ & $2(28.6)$ & & $2(28.6)$ & $3(42.9)$ & $2(28.6)$ & \\
\hline & Not aware of use & $4(21.1)$ & $3(75.0)$ & $1(25.0)$ & & $0(0.0)$ & $0(0.0)$ & $1(25.0)$ & $3(75.0)$ & & $0(0.0)$ & $2(50.0)$ & $2(50.0)$ & \\
\hline \multirow{4}{*}{$\begin{array}{l}\text { Interdental } \\
\text { cleaning item } \\
(n=137)\end{array}$} & Dental floss & $72(52.5)$ & $36(50.0)$ & $36(50.0)$ & \multirow[t]{4}{*}{0.139} & $3(4.2)$ & $20(27.8)$ & $13(18.1)$ & $36(50.0)$ & \multirow[t]{4}{*}{0.691} & $7(9.7)$ & 21(29.2) & $44(61.1)$ & \multirow[t]{4}{*}{$0.018^{*}$} \\
\hline & Tooth pick & $62(45.3)$ & $44(71.0)$ & $18(29.0)$ & & $6(9.7)$ & $17(27.4)$ & $15(24.2)$ & $24(38.7)$ & & $15(24.2)$ & $21(29.2)$ & $26(41.9)$ & \\
\hline & $\begin{array}{l}\text { Interdental } \\
\text { brushes }\end{array}$ & $2(1.5)$ & $1(50.0)$ & $1(50.0)$ & & $0(0.0)$ & $1(50.0)$ & $0(0.0)$ & $1(50.0)$ & & $2(100.0)$ & $0(0.0)$ & $0(0.0)$ & \\
\hline & Others & $1(0.7)$ & $1(100.0)$ & $0(0.0)$ & & $0(0.0)$ & $0(0.0)$ & $1(100.0)$ & $0(0.0)$ & & $0(0.0)$ & $0(0.0)$ & $1(100.0)$ & \\
\hline \multirow{3}{*}{$\begin{array}{l}\text { Time of } \\
\text { interdental } \\
\text { cleaning } \\
(n=137)\end{array}$} & After brushing & $5(3.7)$ & $1(20.00$ & $4(80.0)$ & \multirow[t]{3}{*}{0.084} & $0(0.00$ & $3(60.0)$ & $1(20.0)$ & $1(20.0)$ & \multirow[t]{3}{*}{0.743} & $0(0.00$ & $5(100.0)$ & $0(0.0)$ & \multirow[t]{3}{*}{$0.020^{*}$} \\
\hline & After eating & $106(77.3)$ & $69(65.1)$ & $37(34.9)$ & & $7(6.6)$ & $26(24.5)$ & $23(21.7)$ & $50(47.2)$ & & $19(17.9)$ & $27(25.5)$ & $60(56.6)$ & \\
\hline & Others & $26(19.0)$ & $12(46.2)$ & $14(53.8)$ & & $2(7.7)$ & $9(34.6)$ & $5(19.2)$ & $10(38.5)$ & & $5(19.2)$ & $10(38.5)$ & $11(42.3)$ & \\
\hline
\end{tabular}


Table 3 Association between participants oral hygiene and year of graduation

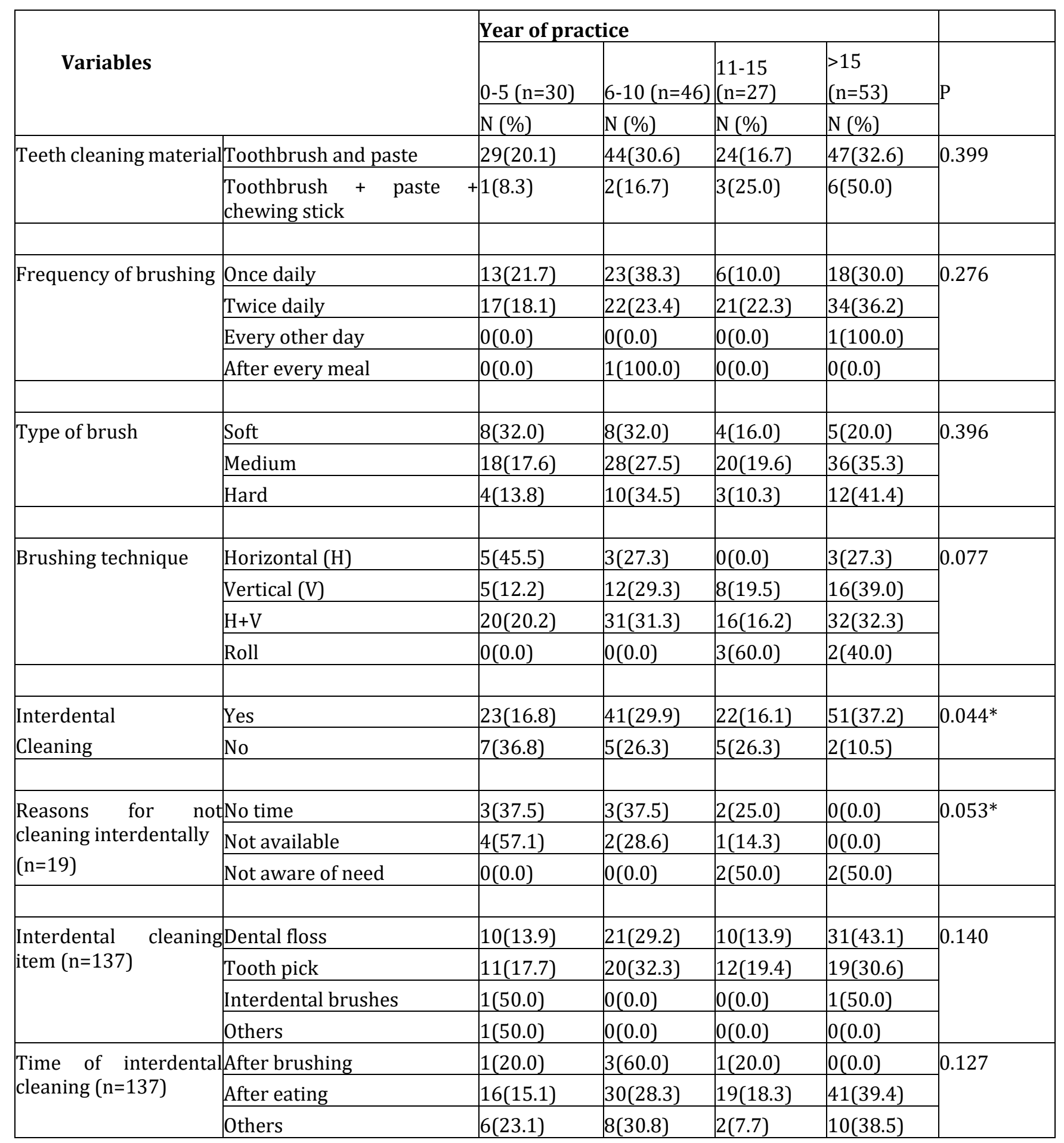

Table 4 showed the association between participants dental service utilization and some demographics. More males $\{59(57.3 \%)\}$ visited the dentists in the past. It was statistically significant that participants in the teaching hospital visited the dentist in the past more than others. One out of every 5 participants regularly visit the dentists; a consultant will likely visit regularly than other designated participants. Statistical analysis showed this to be significant. Reasons given by participants for non-utilization of dental services were various, ranging from no time to fear of dental treatment. More males, $\{35(58.3 \%)\}$ and more consultants $\{27(45 \%)\}$ did not have time and equal number of residents and senior registrars felt they have no dental problem. Statistical analysis showed this to be significant. 
Table 4 Association between dental service utilization and participants demographics

\begin{tabular}{|c|c|c|c|c|c|c|c|c|c|c|c|c|c|c|}
\hline \multirow{3}{*}{\multicolumn{2}{|c|}{ Variables }} & \multirow{3}{*}{\begin{tabular}{|c|} 
Total \\
$\mathrm{N}(\%)$ \\
\end{tabular}} & \multicolumn{2}{|c|}{ Gender } & \multirow{3}{*}{$\mathrm{P}$} & \multicolumn{4}{|c|}{ Designation } & \multicolumn{4}{|c|}{ Centre } & \multirow{3}{*}{$\mathrm{p}$} \\
\hline & & & & & & House & & Senior & & \multirow[t]{2}{*}{$\mathrm{P}$} & Private & State & Federal & \\
\hline & & & $\mathrm{N}(\%)$ & $\mathrm{N}(\%)$ & & $\mathrm{N}(\%)$ & $\mathrm{N}(\%)$ & $\mathrm{N}(\%)$ & $\mathrm{N}(\%)$ & & $\mathrm{N}(\%)$ & $\mathrm{N}(\%)$ & $\mathrm{N}(\%)$ & \\
\hline \multirow{2}{*}{$\begin{array}{l}\text { Previous } \\
\text { dental } \\
\text { Visit } \\
(n=156) \\
\end{array}$} & Yes & $103(66.0)$ & $59(57.3)$ & $44(42.7)$ & \multirow{2}{*}{0.290} & $7(6.8)$ & $25(24.3)$ & $21(20.4)$ & $50(48.5)$ & \multirow[t]{2}{*}{0.378} & $14(13.6)$ & $31(30.1)$ & $58(56.3)$ & \multirow[t]{2}{*}{$0.050^{*}$} \\
\hline & No & $53(34.0)$ & $35(66.0)$ & $18(34.0)$ & & $4(7.5)$ & $17(32.1)$ & $14(26.4)$ & $18(34.0)$ & & $14(26.4)$ & $19(35.8)$ & $20(37.7)$ & \\
\hline \multirow{5}{*}{$\begin{array}{l}\text { Reasons } \\
\text { for past } \\
\text { dental } \\
\text { visits } \\
n=(103)\end{array}$} & Check up & $16(16.6)$ & $5(31.3)$ & $11(68.8)$ & \multirow[t]{5}{*}{0.112} & $1(6.3)$ & $7(43.8)$ & $1(6.3)$ & $7(43.8)$ & \multirow[t]{4}{*}{0.456} & $3(18.8)$ & $5(31.3)$ & $8(50.0)$ & \multirow[t]{4}{*}{0.231} \\
\hline & Scaling \& Polishing & $41(39.8)$ & $27(65.9)$ & $14(34.1)$ & & $5(12.2)$ & $9(22.0)$ & $9(22.0)$ & $18(43.9)$ & & $7(17.1)$ & $14(34.1)$ & $20(48.8)$ & \\
\hline & Extraction & $16(15.6)$ & 11(68.8) & $5(31.3)$ & & $1(6.3)$ & $4(25.0)$ & $5(31.3)$ & $6(37.5)$ & & $2(12.5)$ & $6(37.5)$ & $8(50.0)$ & \\
\hline & Fillings & $9(8.7)$ & $6(66.7)$ & $3(33.3)$ & & $0(0.0)$ & $2(22.2)$ & $1(11.1)$ & $6(66.7)$ & & $1(11.1)$ & $3(33.3)$ & $5(55.6)$ & \\
\hline & Others & $21(20.3)$ & $10(47.6)$ & $11(52.4)$ & & $0(0.0)$ & $3(14.3)$ & $5(23.8)$ & $13(61.9)$ & & $1(4.8)$ & $3(14.3)$ & $17(81.0)$ & \\
\hline \multirow{2}{*}{$\begin{array}{l}\text { Regular } \\
\text { dental } \\
\text { visits } \\
(n=156)\end{array}$} & Yes & 21(13.5) & $15(71.4)$ & $6(28.6)$ & \multirow[t]{2}{*}{0.261} & $1(7.4)$ & $4(19.0)$ & $1(4.8)$ & $15(71.4)$ & \multirow[t]{2}{*}{$0.038^{*}$} & $4(19.0)$ & $4(19.0)$ & $13(61.9)$ & \multirow[t]{2}{*}{0.371} \\
\hline & No & $135(86.5)$ & $79(58.5)$ & $56(41.5)$ & & $10(7.4)$ & $38(28.1)$ & $34(25.2)$ & $53(39.3)$ & & $24(17.8)$ & $46(34.1)$ & $65((48.1)$ & \\
\hline \multirow{4}{*}{$\begin{array}{l}\text { Reason for } \\
\text { non- } \\
\text { regular } \\
\text { visit } \\
(n=135)\end{array}$} & No time & $60(38.5)$ & $35(58.3)$ & $25(41.7)$ & 0.503 & $6(10.0)$ & $16(26.7)$ & 11(18.3) & $27(45.0)$ & 0.109 & $9(15.0)$ & $20(33.3)$ & $31(51.7)$ & \multirow[t]{4}{*}{$0.001^{*}$} \\
\hline & No dental problem & $62(39.7)$ & $34(54.8)$ & $28(45.2)$ & & $4(6.5)$ & $20(32.3)$ & $20(32.2)$ & $18(29.0)$ & & $12(19.4)$ & $24(38.7)$ & $26(41.9)$ & \\
\hline & Bad past experience & $7(4.5)$ & $5(71.4)$ & $2(28.6)$ & & $0(0.0)$ & $1(14.3)$ & $0(0.0)$ & $6(85.7)$ & & $3(42.9)$ & $1(14.3)$ & $3(42.9)$ & \\
\hline & Fear of treatment & $6(3.8)$ & $5(83.3)$ & 1(16.7) & & $0(0.0)$ & $1(16.7)$ & $3(50.0)$ & $2(33.3)$ & & $0(0.0)$ & $1(16.7)$ & $5(83.3)$ & \\
\hline
\end{tabular}


The crosstab of participants dental service utilization with year of practise showed that more participants with over 15 years practise visited the dentist in the past for treatments. Only 21(13.5\%) go regularly. Twice the participants $\{28(45.2 \%)\}$ with six to ten years of practice compared to those with more than fifteen years of practice $\{14(22.6 \%)\}$ did not access dental service because they felt they had no dental problem. Statistical analysis however showed no statistical difference. Table 5

\begin{tabular}{|c|c|c|c|c|c|c|c|}
\hline & & & Year of practi & & & & \\
\hline Variables & & Total & $0-5(n=30)$ & $\begin{array}{l}6-10 \\
(n=46)\end{array}$ & $\begin{array}{l}11-15 \\
(n=27)\end{array}$ & $\begin{array}{l}>15 \\
(n=53)\end{array}$ & $\mathrm{p}$ \\
\hline & & $\mathrm{N}(\%)$ & $\mathrm{N}(\%)$ & $\mathrm{N}(\%)$ & $N(\%)$ & $\mathrm{N}(\%)$ & \\
\hline Previous dental & Yes & $103(66.0)$ & $150.060(14.6)$ & $28(27.2)$ & $16(15.5)$ & $44(42.7)$ & $0.010^{*}$ \\
\hline & No & $53(34.0)$ & $15(28.3)$ & $18(34.0)$ & $11(20.8)$ & $9(17.0)$ & \\
\hline Reasons for past & Check up & $16(15.6)$ & $2(12.5)$ & $5(31.3)$ & $2(12.5)$ & $7(43.8)$ & $0.021^{*}$ \\
\hline aental visit & Scaling \& Polishing & $41(39.8)$ & $10(24.4)$ & $12(29.3)$ & $6(14.6)$ & $13(31.7)$ & \\
\hline & Extraction & $16(15.6)$ & $2(12.5)$ & $6(37.5)$ & $3(18.8)$ & $5(31.3)$ & \\
\hline & Fillings & $9(8.7)$ & $0(0.0)$ & $1(11.1)$ & $0(0.0)$ & $8(88.9)$ & \\
\hline & Others & $21(20.3)$ & $1(4.8)$ & $4(19.0)$ & $5(23.8)$ & $11(52.4)$ & \\
\hline Regular dental & Yes & $21(13.5)$ & $3(14.3)$ & $4(19.0)$ & $0(0.0)$ & $14(66.7)$ & $0.050^{*}$ \\
\hline Visits & No & $135(86.5)$ & $27(20.0)$ & $42(31.1)$ & $27(20.0)$ & $39(28.9)$ & \\
\hline Reasons for no & No time & $60(38.5)$ & $18(30.0)$ & $13(21.7)$ & $14(23.3)$ & $15(25.0)$ & 0.248 \\
\hline $\begin{array}{l}\text { regular dental } \\
\text { visits }(n=135)\end{array}$ & No dental problem & $62(39.7)$ & $9(14.5)$ & $28(45.2)$ & 11(17.7) & $14(22.6)$ & \\
\hline & Bad past experience & $7(4.5)$ & $0(0.0)$ & $0(0.0)$ & $0(0.0)$ & $7(100.0)$ & \\
\hline & Fear of treatment & $6(3.8)$ & $0(0.0)$ & $1(16.7)$ & $2(33.3)$ & $3(50.0)$ & \\
\hline
\end{tabular}

\section{Discussion}

One hundred and fifty-six participants were recruited for this study. More males $\{94(60.3 \%)\}$ than females $\{62(39.7 \%)\}$. Age ranged between 23 and 72 years with a mean age of $41.6 \pm 11.18$ years.

Oral hygiene aids that can be used to maintain good oral hygiene are toothbrushes and fluoridated toothpastes. In addition, in Nigeria and other parts of the world; the use of chewing sticks as traditional cleaning aids has been recognized [22-24]. Chewing sticks have been shown to have beneficial effects on oral health [23,24]. In this study almost all the participants (92.3\%) used toothbrush and toothpaste in cleaning their teeth. This is similar to a study done in Lagos and other parts of the world among medical doctors that reported that $99.1 \%$ and over $90 \%$ of their participants respectively used same $[25,26]$. In this study, $7.7 \%$ of participants used chewing stick in addition to tooth brushes in cleaning their teeth. This is comparable to the study done in Ile-ife in Nigeria that reported that $7 \%$ of their participants used chewing sticks as an additional oral hygiene aid [27], and contrasted with a study done in Lagos that reported a higher percentage of $12.8 \%$ [25].

Of all the available toothbrushing techniques, the roll and bass techniques are highly recommended because they minimize trauma to the gingival tissues. This study recorded that $3.2 \%$ of participants; more females than males, used the roll technique. This is lower than that recorded in the Lagos study [25]. This showed a poor knowledge of the recommended brushing techniques among the participants. $63.5 \%$ of participants; more males, more consultants and more participants in the federal hospital used both vertical and horizontal scrubs. In this study, fewer participants 
$11(7.1 \%)$ used the horizontal scrub only. This is higher than a study done in Lagos, Nigeria among medical interns that recorded that $5.6 \%$ of their participants used the horizontal scrub technique and that done among undergraduate students in Ile-ife that recorded $37.1 \%[25,27]$.

Brushing twice daily, (before going to bed and after breakfast) has been reported to enhance oral hygiene [28]. In this study, three-fifth (60.3\%) brushed twice daily; more males, greater number of consultants and more participants in federal hospital. This is comparable to an India study [29] among dental professionals that recorded 55.9\% but higher than other studies in Nigeria that recorded $24.2 \%$ and $39.9 \%[25,27]$. This showed that there is a higher awareness of recommended frequency of toothbrushing among our participants.

In this study, $65.4 \%$ of participants, more males, consultants, more participants in the federal hospital and those with more than 15 years of medical practice used medium bristled toothpastes. This is comparable to a study among medical house officers in Benin-city, Nigeria that reported a $68 \%$ frequency of use among their participants with no gender difference [30].

Since brushing alone does not adequately clean the teeth because they cannot be used interdentally, the use of interdental cleaning aids such as dental floss and interdental brushes have been encouraged [31]. In this study, half of the participant used dental floss and this is highly commendable and not surprising because of the caliber of the participants. There was no gender difference in the use of dental floss in this study. Other studies reported lower frequencies and more females than males using dental floss [32- 39].

Regular dental visits once every six months is highly recommended for good oral health. In this study, $34 \%$ of participants had never accessed dental care and only $13.5 \%$ and interestingly more males than females access care regularly. This may be due to increased awareness of the need to access dental care among males. Past studies had reported that males do not seek health care as females because they are busy and only come when in extreme pain. [4044]. The study in Benin-city recorded more females than males accessing dental care [30]. This study recorded a poor dental attendance and this is comparable to other studies done in Nigeria that reported same among other workers $[45,46]$. About two-fifth of those who visited did scaling and polishing, a preventive measure for dental disease and treatment for gingival inflammation. This is in contrast to other studies that reported dental pain as the reason for seeing the dentist [40-46].

\section{Compliance with ethical standards}

\section{Acknowledgments}

The authors acknowledge all medical colleagues who participated in this study.

\section{Disclosure of conflict of interest}

The authors declare no conflict of interest.

\section{Statement of informed consent}

Informed consent was obtained from all individual participants included in the study.

\section{References}

[1] National Institute of Dental and Craniofacial Research. A report of the Surgeon General. US Department of Health and Human Services. Rockville MD: National Institute of Dental and Craniofacial Research; 2000.

[2] Shailee F, Vikas F, Vinay B, Arun ST, Sheila V, Purmima T. Oral health knowledge and practices among primary healthcare workers in Shimla District, Himachal Pradesh, India. Epidemiological Study 2018; 29(6):858-861.

[3] Huttenhower C, Gevers D, Knight R, Abubucker S, Badger JH, Chinwalla AT et al. Structure, Function and Diversity of the Healthy Human Microbiome. Mature 2012; 486(7402):207-214.

[4] Kilian M, Chapple ILC, Hannig M, March PD, Meuric AM, Pedersen M, et al. The oral microbiome - an update for oral healthcare professionals. Br Dent J 2016; 221:657-666.

[5] Mahasneh SA, Mahasneh AM. Probiotics: A Promising Role in Dental Health. Dent J (Basel) $2017 ; 5$ (4):26. 
[6] March D. How is the development of dental biofilms influenced by host? J Clin Periodol 2011; 38:28-35.

[7] Bartold VK. "Periodontitis: a host-mediated disruption of microbial homeostasis. Unlearning learned concepts". Periodontal 2000, 2012; 62(1):203-217.

[8] Creeth JE, Gallagher A, Sowinski J, Bowman J, Barrett K, Lowe S, et al. The effect of brushing time and dentifrice on dental plaque removal in vivo. J Dent Hyg. 2009; 83(3):111-116.

[9] Accepted Dental Therapeutics. Section III (40th ed.). Council on Dental Therapeutics.

[10] Cockerill 3rd FR, Wilson WR, Van Scoy, RE. Travelling toothpicks. Mayo Clinic proceedings 1983; 58(9):613.

[11] Siu FL, Kimberly E. Toothpick injury mimicking renal colic: case report and systematic review. Journal of Emergency Medicine 2002; 23(1):35-38.

[12] Lawrence DB. Toothpick-related injuries in the United States, 1979 through 1982.JAMA 1984; 252(6):796-797.

[13] Donald BB. Venturesome Toothpick: A continuing source of Pyogenic Hepatic Abscess. JAMA 1984; 252(6):797798.

[14] Yun-Chung C, Shu-Hang N, Chin-Feng T, Koon-Kwan N, Yung-Liang Wan. Hepatic inflammatory mass secondary to toothpick perforation of the stomach: triphasic CT appearances. Clinical Imaging 2000; 24(2):93-95.

[15] Tsung-Hsien C, Kao-Lang L, Yi-Chia L, Han-Mo C, Jaw-Town L, Hsiu-Po W. Sonographic diagnosis of a toothpick traversing the duodenum and penetrating into the liver. Journal of Clinical Ultrasound 2006; 34(5):237-240.

[16] Main P, Leake J, Burman D. Oral health care in Canada - a view from the trenches. J Can Dent Assoc 2006; $72(4): 319$.

[17] Leake JL. Access and care: reports from Canadian dental education and care facilities. J Can Dent Assoc 2005; 71(7):469-71.

[18] Kiyak HA, Reichmuth M. Barriers to and enablers of older adults' use of dental services. J Dent Educ 2005; 69(9):975-86.

[19] Dolan TA, Atchinson K, Huynh TN. Access to dental care among older adults in the United States. J Dent Educ 2005; 69(9):961-74. 23. Seniors Oral Health Collaboration. The oral health of seniors in Nova Scotia, policy scan and analysis synthesis report. Halifax: Nova Scotia Department of Health; 2006. 24.

[20] Locker D. Does dental care improve the oral health of older adults? Community Dent Health 2001; 18(1):7-15.

[21] Anyanechi CE, Saheeb BD. Reasons underlying failure to seek dental treatment among patients presenting in a Nigeria Tertiary Hospital. Journal of Medicine and Biomedical Research 2013; 12(1):37-45.

[22] Mittal R, Wong M, Koh G, Ong D, Lee Y, Tan M, et al. Factors affecting dental service utilisation among older Singaporeans eligible for subsidized dental care - a qualitative study. BMC 2019 Public Health; 19:1075.

[23] Bukar A, Danfillo IS, Adeleke OA, Ogunbodede EO. Traditional oral health practices among Kanuri women of Borno State, Nigeria. Odontostomatol Trop 2004; 27:25-31.

[24] al-Otaibi M. The miswak (chewing stick) and oral health. Studies on oral hygiene practices of urban Saudi Arabians. Swed Dent J Suppl 2004; 167:2-75.

[25] Malik AS, Shaukat MS, Qureshi AA, Abdur R. Comparative effectiveness of chewing stick and toothbrush: A randomized clinical trial. N Am J Med Sci 2014; 6:333-7.

[26] Iwuala SO, Umezudike KA, Ozoh OB, Fasanmade OA. Oral self-care, dental attendance and self-perceived oral health status among internal medicine residents in Nigeria. Eur J Gen Dent 2015; 4(2):79-86.

[27] Folayan MO, Khami MR, Folaranmi N, Popoola BO, Sofola O0, Ligali TO, et al. Determinants of preventive oral health behaviour among senior dental students in Nigeria. BMC Oral Health 2013; 13:28.

[28] Akhimie EE, Oginni FO, Oginni AO. A study of tooth brushing pattern and its effects on dental tissues in Obafemi Awolowo University students. Niger Dent J 2013; 21:70-6.

[29] Attin T, Hornecker E. Tooth brushing and oral health: How frequently and when should tooth brushing be performed? Oral Health Prev Dent 2005; 3:135-40.

[30] Azodo CC, Unamatokpa B. Gender difference in oral health perception and practices among Medical House Officers. Russian Open Med J 2012; 1:0208. 
[31] Gluch JI. As an adjunct to tooth brushing, interdental brushes (IDBs) are more effective in removing plaque as compared with brushing alone or the combination use of tooth brushing and dental floss. J Evid Based Dent Pract 2012; 12:81-3

[32] Gopinath V. Oral hygiene practices and habits among dental professionals in Chennai. Indian J Dent Res 2010; 21:195-200.

[33] Fukai K, Takaesu Y, Maki Y. Gender differences in oral health behaviour and general health habits in an adult population. The Bulletin of Tokyo 1999; 40(4): 187-193.

[34] Zadik Y, Galor S, Lachmi R, Proter N. Oral self-care habits of dental and healthcare providers. Int J Dent Hyg 2008; 6:354-60.

[35] Howe M, Leidel A, Krishnan SM, Weber A, Rubenfire M, Jackson EA. Patient-related diet and exercise counseling: Do providers' own lifestyle habits matter? Prev Cardiol 2010; 13:180-5.

[36] Ostberg AL, Halling A, Lindblad U. A gender perspective of self-perceived oral health in adolescents: Associations with attitudes and behaviours. Community Dent Health 2001; 18:110-6.

[37] Komabayashi T, Kwan SY, Hu DY, Kajiwara K, Sasahara H, Kawamura M. A comparative study of oral health attitudes and behaviour using the Hiroshima University - Dental Behavioural Inventory (HU-DBI) between dental students in Britain and China. J Oral Sci 2005; 47:1-7.

[38] Polychronopoulou A, Kawamura M. Oral self-care behaviours: Comparing Greek and Japanese dental students. Eur J Dent Educ 2005; 9:164-70.

[39] Kawamura M, Ikeda-Nakaoka Y, Sasahara H. An assessment of oral self-care level among Japanese dental hygiene students and general nursing students using the Hiroshima University - Dental Behavioural Inventory (HU-DBI): Surveys in 1990/1999. Eur J Dent Educ 2000; 4:82-8.

[40] Varun V, Gautam P, Monita K. Gender differences in utilization of Preventive care services in United states. Journal of Women's Health; 21(2):140-145.

[41] Redondo-Sendino Á, Guallar-Castillón P, Banegas JR, Rodriguez-Artlejo F. Gender differences in the utilization of health-care services among the older adult population of Spain. BMC Public Health 2006'; (6):155-164.

[42] Kenagy GP, Linsk NL, Bruce D, Warneche R, Gordon A, Wagaw F, et al. Service utilization, service barriers and gender among HIV-positive consumers in primary care. Aids Patient Care and STD's 2003: 235-244.

[43] Nguyen L, Häkkinen U, Rosenqvist G. Determinants of Dental Service Utilization among Adults. The Case of Finland. Health Care Manage Sci 2005; (8): 335-345.

[44] Erik S, Magne R, Gerd K, Einar B. Gender-based differences in factors related to non-utilization of dental care in young Norwegians. A longitudinal study. European Journal of Oral Sciences 2003; 111(5): 377-382

[45] Umeizudike KA, Ayanbadejo PO, Taiwo OA, Savage KO, Alade GO. Utilization of Dental Services by Administrative workers in a Tertiary Health Institution in Lagos, Nigeria - A Pilot Study. Niger Q J Hosp Med 2014; 24:86-90.

[46] Lawal FB, Olawole WO, Sigbeku OF. Self-rating of oral health status by student dental surgeon assistants in Ibadan, Nigeria - A pilot survey. Ann Ib Postgrad Med 2013; 11:12-17. 